\title{
Demiryolu Yük Taşımacılığının Çok Türlü Rotalara Etkisinin Vaka Analizi ile İncelenmesi: Hatay-Van
}

\author{
Ömer Faruk CANSIZ, Kevser ÜNSALAN* \\ İskenderun Teknik Üniversitesi, İșaat Mühendisliği Bölümü, Hatay \\ (ORCID:0000-0001-6857-2513) (ORCID:0000-0002-9163-4855)
}

\begin{abstract}
Öz
Çalışmada, güzergâh karar değiş̧kenleri ve bu değişkenlere bağlı performans indeksi dikkate alınarak güzergâh karşılaştırması yapılmaktadır. Çalışmanın amacı güzergâh karşılaşııımasında, tek türlü konteyner yük taşımacılığının dışına çıkıp çok türlü taşımacılığın avantajlarını ön plana çıkarırken, ulaşım coğrafyasının çok türlü taşımacıllğa olan etkisi de incelenmektedir. Bu nedenle Türkiye'nin güneyinde filtre sanayisi gelişmiş olan Hatay ilinden, Türkiye'nin doğusundaki Van iline güzergâh karşılaştırması yapılmaktadır. Hatay ile Van arasında, ulaşım coğrafyasından dolayı sadece bir çeşit tek türlü yük taşımacılığı güzergâhı oluşturulmaktadır. Bunun yanı sıra iki il arasında karayolu, demiryolu ve feribot taşımacılığının birleştirilebilmekte ve böylece birden fazla çok türlü yük taşımacılık güzergâhı oluşturulabilmektedir. Güzergâhlar, rota seçiminde önemli yere sahip olan yakıt tüketimi, taşıma maliyeti, taşıma süresi ve $\mathrm{CO}_{2}$ salınımı parametrelerine bağlı olarak incelenmektedir. Yapılan hesaplar sonucunda güzergâhların performans indeksleri incelendiğinde, çok türlü 3 rotasının diğer rotalar içerisinde dört parametreye bağlı olarak en uygun güzergâh olduğu bulunmaktadır. Burada şunu belirtmek gerekir ki, Hatay ile Van arasında tek türlü demiryolu taşımacılı̆̆ı yapılamazken, feribot taşımacıllğı ile avantajlı çok türlü taşımacılık güzergâhları oluşturulmaktadır.
\end{abstract}

Anahtar kelimeler: Çok Türlü Taşımacılık, Tek Türlü Taşımacılık, Rota Optimizasyonu.

\section{Investigation of the Effect of Railway Freight on Multimodal Routes by Case Study: Hatay-Van}

\begin{abstract}
In this study, route comparison is made by considering route decision variables and performance index related to these variables. The aim of the study is highlight the advantages of multimodal transportation by out of the unimodal container freight transportation and also to examine the effect of transportation geography on multimodal transportation. Therefore, between Hatay province in southern Turkey and Van province in eastern Turkey route comparison are studied. There is only one kind of unimodal freight transportation route between Hatay and Van due to the transportation geography. In addition, it is possible to combine road, rail and ferry transport between the two provinces, thus creating more than multimodal freight transport route. The routes are examined according to the parameters of fuel consumption, transportation cost, transportation time and $\mathrm{CO}_{2}$ emission which have an important place in route selection. When the performance indexes of the routes are examined as a result of the calculations, it is found that multimodal route 3 are the most suitable route among the other routes depending on the four parameters. It should be noted here that while there is no unimodal railway transportation between Hatay and Van, advantageous of multimodal transportation routes are being established by ferry transportation and railway transportation.
\end{abstract}

Keywords: Multimodal Transport, Unimodal Transport, Route Optimization.

*Sorumlu yazar: kevser.keskin@iste.edu.tr

Geliş Tarihi: 28.12.2018, Kabul Tarihi: 17.07.2019 


\section{Giriş}

Hatay'da konteyner kullanılarak taşıması yapılan filtre malzemesinin Hatay'ın sanayisinde önemli bir yeri vardır ve Türkiye'nin birçok iline satışı yapılmaktadır. Filtre yükünün taşınmasında kullanılan konteyner, çok türlü taşımacılık yapılmasında birçok avantajı beraberinde getirmektedir. $\mathrm{Bu}$ avantajlardan en önemlisi çok türlü taşımacılıkta modlar arası yük aktarımında konteynerler, büyük kolaylık sağlamaktadır. Demirlioğlu [1], konteyner taşımacıllğg 1 ve Türkiye'nin liman altyapılarını incelemekte ve konteyner taşımacıllı̆ııın avantajlarını liman altyapı imkânlarının geliştirilmesi üzerine öneriler sunmaktadır. Ateş vd. [2] önceki çalışmaları destekler nitelikte denizyolu taşımacıllı̆̆nda konteyner taşımacılığının yerini araştırmakta ve Türkiye'nin konteyner taşımacılığındaki mevcut durumunu inceleyerek, eksiklikleri tespit etmektedir. Ateş vd. [3] başka bir çalışmasında Karadeniz etrafındaki konteyner taşımacılığı yapılabilen limanları veri zarflama analizi ile incelemekte ve bu limanların konteyner taşımacılığı için verimli olup olmadığına karar vermektedir. Analiz sonucu Karadeniz etrafında en verimli limanlar Poti ve Novorossisk terminalleri çıkmaktadır.

Çok türlü taşımacılıkta taşıma kabı seçimi öneminin yanı sıra uygun yük aktarma istasyonlarının belirlenmesi de oldukça önemlidir. En uygun mod değişim noktalarının belirlenmesi, en iyi rotanın belirlenmesine bağlıdır. Bu nedenle en uygun rotaların oluşturulması, taşımacılık maliyetlerinin önemli ölçüde düşmesine sebep olmaktadır. Uygun rota belirleme ile çok türlü taşımacıllı̆ı̆ı yapılması, taşımacılıkla ilgili meydana gelen birçok olumsuz durumun da düzelmesine yardımcı olmaktadır. Çok türlü taşımacılığın avantajları ile ilgili birçok araştırma yapılmaktadır [4,5]. Sahin vd. [6] çalışmalarında yıllık kargo potansiyeli ve rotaların doluluk oranını dikkate alarak, intermodal ve çok türlü taşımacılık rotalarının, uygun filo boyutunun ve uygun araç kapasitelerinin belirlenmesine katkıda bulunduğunu belirtmektedir.

Çok türlü taşımacılıkta yük türüne, ağırlığına, hacmine, mali değerine göre ulaşım modu seçimi de oldukça önemlidir. Demiryolu taşımacılığı karayolu taşımacılığına kıyasla enerji tüketimi bakımından oldukça avantajlıdır [7-12]. Çok türlü taşımacılıkta, demiryollarının rotanın içerisine girmesi olumlu sonuçları beraberinde getirmektedir. Bu amaçla Vitoşoğlu ve Evren [13] demiryolu ağırlıklı kombine taşımacılık araştırması yapmaktadır. Bunun için yük ve yolcu taşımacılığı üzerinde uygulanabilir denklemler geliştirmektedir.

Çok türlü taşımacılıkta demiryolu taşımacılığının öneminin yanı sıra, üç tarafı denizlerle kaplı yurtiçi ve yurtdışı deniz taşımacılığının uygun olduğu Türkiye'de çok türlü taşımacılık ve denizyolu taşımacılığı uyumu da birçok çalışmada incelenmektedir [14]. Balık vd. [15] Türkiye ve Dünya deniz taşımacılığını karşılaştırmakta ve denizyolu ile diğer taşıma modlarının birleştirilmesinin uluslararası ticarette birçok avantajı beraberinde getirec eği vurgulanmaktadır. Saatçioğlu ve Saygılı [16], intermodal taşımacılıkta demiryolu ve denizyolu birleşiminde etkili olan parametreleri araştırmaktadır.

Taşımacılıkta en önemli konulardan biriside nakliye maliyetlerinin en doğru şekilde tahmin edilmesidir. Bu nedenle karayolu, denizyolu ve demiryolu ulaşım modlarında teknik, ekonomik ve operasyonel parametrelere dayanan gerçekçi bir analiz yapılması gerekmektedir [17]. Ozbay vd. [18] çoklu taşımacılıkta rota başına düşen marjinal maliyet hesabı için statik trafik ve mikroskobik trafik simülasyon yazılımlarını kullanarak tahmin yapmaktadır. Janic, intermodal ve karayolu taşımacılık maliyetlerini iç ve dış olmak üzere iki gruba ayırmaktadır. İç maliyetler başlığı altında nakliye, terminal operatörlerinin getirdiği operasyonel maliyetleri incelemekte, dış maliyetler başlığı altında ise taşıma araçlarından kaynaklı hava kirliliği, gürültü kirliliği, trafik tıkanıklığı ve trafik kazalarını incelemektedir [19]. Chang [20], uluslararası intermodal taşımacıllğı çoklu hedef, teslimat süresi ve taşıma maliyetleri olmak üzere üç kategoride ele alarak sezgisel bir algoritma önererek optimize etmektedir.

Çok türlü taşımacılıkta uygun ulaşım modu seçiminde yük türü, birçok parametre seçimini etkilemesinden kaynaklı olarak literatürde bu konu üzerine vaka analizi çalışmaları yoğunlaşmaktadır. Bu nedenle bu çalışmada yük türü olarak filtre yükü seçilmekte ve filtre fabrikalarından alınan bilgiler doğrultusunda filtre yükünün taşınmasına uygun olan standart $40^{\prime}$ konteyner ile taşınması dikkate alınmaktadır. Belirlenen yük türü için filtre fabrikasından alınan bilgilere göre, filtre çeşitlerine bağlı olarak üç farklı yük ağırlığı ve yük mali değeri belirlenmektedir. Çalışmada Türkiye'nin Akdeniz bölgesi ile Doğu Anadolu Bölgesi arasındaki ulaşım coğrafyasının çok türlü taşımacılık rota seçimini ne yönde etkilediğini görebilmek amacıyla Hatay-Van arasında vaka analizi çalışması yapılmaktadır. İki il arasında oluşturulan rotaların karşılaştırılması için yakıt tüketimi, maliyet, taşıma süresi, emisyon, performans indeksi gibi beş farklı karar değişkeni belirlenmektedir. 


\section{Materyal ve Metot}

\subsection{Yakıt tüketimi}

Rota seçiminde en önemli parametrelerden biri maliyettir. Maliyeti etkileyen ana bileşenlerden biri ise taşııın yakıt tüketimidir. Bu çalışmada yakıt tüketiminin güzergâh karar değişkeni olarak alınmasının nedenleri, maliyeti oluşturan ana bileşenlerden biri olmasının yanı sıra, Dünya'da yenilenemez enerji kaynaklarından biri olması da etkilidir. Türkiye'de ulaştırma sektörü içerisinde petrol ürünlerinin tüm sektörler içindeki payı \%11,19'dur [21]. Petrol ürünlerinin tüketiminde ulaştırma sektörünün pay1 azımsanmayacak bir orana sahip olmasından dolayı çalışmada güzergâh karar değişkeni olarak alınmaktadır. Yakıt tüketim hesabı karayolu ve demiryolu ulaşım türleri için, farklı ulaşım aracı tiplerine göre ayrı ayrı hesaplanmaktadır.

\subsubsection{Karayolu yakıt tüketimi}

Karayolu taşımacılığında yakıt tüketim hesabı yapılırken, taşııın yüklü olarak varış yerine gittiği ve yüksüz olarak başlangıç noktasına geri geldiği kabul edilmektedir. Taşıtın taşıyacağı maksimum yük ise 26 ton olarak belirlenmektedir. Taşıtın 26 ton ile yüklü iken 100 km'de 40 litre, boş iken ise 100 km'de 30 litre dizel akaryakıt tükettiği kabul edilmektedir [14]. Karayolu yakıt tüketimi Denklem 1'e göre hesaplanmaktadır.

$$
\mathrm{YT}_{\text {karayolu }}=\left((\mathrm{YM}) /(\mathrm{MY}) \times\left(\mathrm{YT}_{\max }-\mathrm{YT}_{\min }\right)+\mathrm{YT}_{\min }\right) \times(\mathrm{M} / 100)+(\mathrm{M} / 100) \times \mathrm{YT}_{\min }
$$

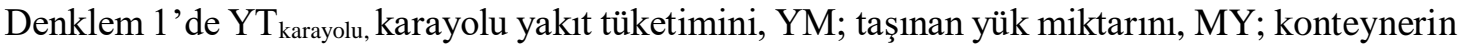
maksimum yük kapasitesini, M; karayolu taşıma mesafesini, $\mathrm{YT}_{\max } 100 \mathrm{~km}$ 'de maksimum yükün taşınmasında tüketilen yakıt miktarını, $\mathrm{YT}_{\min }$ boş iken tükettiği yakıt miktarını göstermektedir.

\subsubsection{Demiryolu yakıt tüketimi}

Demiryolu yük taşımacıllı̆ı için yakıt tüketimi hesabı Denklem 2'ye göre hesaplanmaktadır. Demiryolu taşımacılığında analizler yapılırken bir lokomotifte 80 adet vagon taşındığ 1 ve bir vagonda bir adet standart konteyner taşındığ kabul edilmektedir. Lokomotifin 100 kilometre de en az 85 en çok ise 100 litre dizel yakıt yaktığı kabul edilmektedir [22]. Bu çalışmada lokomotifin en fazla yakıt tükettiği durum ele alınarak en elverişsiz şartlar değerlendirilmektedir.

$$
\mathrm{YT}_{\text {demiryolu }}=((\mathrm{M} / 100) \times \mathrm{OYT}) / \mathrm{KS}
$$

Bu denklemde $\mathrm{YT}_{\text {demiryolu }}$ demiryollarında konteyner başına düşen yakıt tüketimini, $\mathrm{M}$ demiryolu taşıma mesafesini, OYT bir lokomotifin 100 kilometrede birim yakıt tüketim miktarını, KS bir lokomotifte taşınan toplam konteyner sayısını göstermektedir.

\subsection{Maliyet hesabı}

Taşımacılık rotalarının belirlenmesinde şirketlerin dikkat ettiği en önemli parametre nakliye ücretleridir. Çok türlü taşımacıllı̆ın maliyete etkisinin bilimsel çalışmalarla ortaya konması şirketlerin çok türlü taşımacılık rotalarını önemsemelerine sebebiyet vermektedir. Çünkü lojistikte en önemli rekabet maliyetlerin düşürülmesi ile sağlanabilmektedir [23].

\subsubsection{Karayolu maliyet hesabı}

Karayolu yük taşımacılı̆̆ında ton başı birim maliyet hesabı Denklem 3 esas alınarak yapılmaktadır. Karayolu maliyeti taşıtın yakıt tüketim miktarı, sürücü ve dolaylı giderler dikkate alınarak hesaplanmaktadır. Dizel yakıt litre fiyatı 2018 in ilk yarısında akaryakıt firmalarından alınan bilgilere göre 5,1 TL/lt alınarak hesap yapılmaktadır. Sürücü ve dolaylı giderler ton baş1 5 TL kabul edilmektedir. 
Dolaylı giderler başlığı altında, karayolu taşımacılığı yapan firmanın muhasebe, yönetici, idareye bağlı giderlerine ek olarak aracın bakım gibi kademe giderleri de yer almaktadır.

$$
\mathrm{M}_{\text {karayolu }}=\left(\mathrm{YT}_{\text {karayolu }} \times \mathrm{YF}_{\text {dizel }}+\mathrm{SDG} \times \mathrm{YM} \times \mathrm{SS}\right) / \mathrm{YM}
$$

Denklemde $\mathrm{M}_{\text {karayolu }}$, karayolunda bir konteyner için hesaplanan ton başı taşımacılık maliyeti; $\mathrm{YT}_{\text {karayolu, }}$ karayolu taşıtının yaktığı yakıt miktarı; $\mathrm{YF}_{\text {dizel, }}$, dizel yakıtın litre fiyatı, SDG ise ton başına sürücü ve dolaylı giderleri, YM ise taşınan yükün miktarını, SS sürücü sayısını göstermektedir.

\subsubsection{Demiryolu maliyet hesabı}

Demiryolu yük taşımacılığında ton başı maliyet hesabı TCDD'nin yayınladığı rapordan alınan birim fiyatlara göre hesaplanmaktadır [24]. Rapordan alınan birim fiyatlara ek olarak yükün mali değerine bağlı kıymet primi hesaba katılmaktadır. Kıymet primi 1000 kilometreden az taşımacılık mesafeleri için yükün mali değerinin 1/1000'i, 1000 kilometreden fazla taşımacılık mesafeleri için ise yükün mali değerinin 2/1000'i alınmaktadır. Demiryolu taşımacılık maliyeti Denklem 4'e göre hesaplanmaktadır.

$$
\mathrm{M}_{\text {demiryolu }}=(\mathrm{TBF} \times \mathrm{YM}+\mathrm{KP}+\mathrm{YB}) / \mathrm{YM}
$$

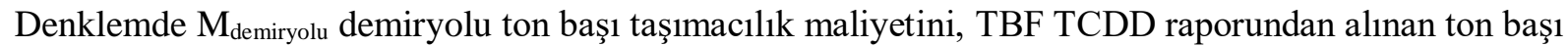
birim fiyatı, YM taşınan yükün ağırlığını, KP ise kıymet primini, YB bir konteynerin vagona yükleme ücretini göstermektedir.

\subsection{Taşımacılık süresi hesabı}

Günümüzde ucuz taşımacılığın yanı sıra, nakliyede en çok dikkat edilen unsur taşıma süresi olarak ön plana çıkmaktadır. Özellikle taze gıdaların taşınmasında zaman faktörü birinci sırada yer almaktadır. Bu nedenle rota seçiminde taşımacılık süresi karar değişkeni olarak ele alınmaktadır.

\subsubsection{Karayolu taşımacılık süresi hesabı}

Karayolu taşımacılık süresinde seyir esnasında geçen süreç, sürücü mola süreleri, yükleme boşaltma süreleri değerlendirmeye alınmaktadır. Yükleme boşaltma süresi $30 \mathrm{dk}$ olarak kabul edilmektedir. Yönetmeliklere göre karayollarında sürücünün 4,5 saat devamlı sürüşten sonra zorunlu 45 dakika mola vermesi gerekmektedir. 24 saat içerisinde ise maksimum araç kullanma süresi 9 saat ile sinırlandırılmaktadır. En az iki sürücü olması halinde her 30 saatlik sürede her bir sürücü minimum 8 saat kesintisiz bir şekilde dinlenmektedir [25]. Yine belirlenen hız sınırlamalarına göre aracın ortalama hızı $80 \mathrm{~km} / \mathrm{sa}$ olarak alınmaktadır [26]. Karayolunda taşımacılık süresi Denklem 5 dikkate alınarak hesaplanmaktadır.

$$
\mathrm{TS}_{\text {karayolu }}=\mathrm{M} / \mathrm{H}+\mathrm{SDS}+\mathrm{YBS}
$$

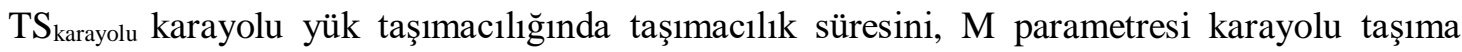
mesafesini, H değeri taşıtın ortalama hızını, SDS sürücü dinlenme sürelerini, YBS ise yükleme boşaltma süresini göstermektedir.

\subsubsection{Demiryolu taşımacılık süresi hesabı}

Demiryolu yük taşımacılığında taşımacılık süresi trenin seyir süresi ve yükleme boşaltma süresi dikkate alınarak hesaplanmaktadır. Trenin yükleme boşaltma süresi 45 dakika olarak alınmaktadır. Türkiye'de yük trenlerinin hızı en fazla $70 \mathrm{~km} / \mathrm{sa}$ olabilmektedir. Avrupa ülkelerinde ise yük trenlerinin hızı 100 $\mathrm{km} / \mathrm{sa}$ hızın üzerine çıkabilmektedir [27]. Bu çalışmada trenin hızı $70 \mathrm{~km} / \mathrm{sa}$ alınarak hesaplamalar yapılmaktadır. Denklem 6' da demiryollarında yük taşımacılığı için taşımacılık süresinin denklemi verilmektedir. 
$\mathrm{TS}_{\text {demiryolu }}=\mathrm{M} / \mathrm{H}+\mathrm{YBS}$

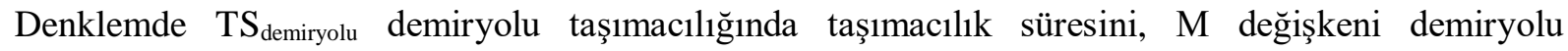
taşımacılığında kat edilen mesafeyi, H parametresi trenin ortalama hızını, YBS ise yükleme boşaltma süresini temsil etmektedir.

\subsection{Emisyon hesabı}

Dünyada iklim değişikliklerinin etkisiyle sera gazı emisyonu araştırılmaya değer bir konu haline gelmektedir. En fazla karbondioksit salınımın olduğu ülkelerden biriside Çin'dir. Çin'de sera gazı salınımlarının azaltılmasına yönelik birçok çalışma mevcuttur [28-30]. Türkiye'de Kyoto Protokolü kapsamında düşük karbon ekonomisi modeli esas alınmaktadır [31]. Bu çalışma da ulaşım sektöründeki sera gazı emisyonunun rota seçimine etkisi incelenmektedir. Karayolu ve demiryolu yük taşımacıllğ için emisyon değerleri Denklem 7 ye göre hesaplanmaktadır [32].

$$
\mathrm{E}=\mathrm{YM} \times \mathrm{D} \times \mathrm{EF}
$$

Denklemde E, gram cinsinden $\mathrm{CO}_{2}$ salınım miktarını, YM taşınan yükün ağırlığını, D taşıma mesafesini ve $\mathrm{EF}$ ise ton baş1 $\mathrm{CO}_{2}$ emisyon faktörünü göstermektedir. Emisyon faktörünün hesabı ise Denklem 8'de verilmektedir [32].

$$
\mathrm{EF}=\mathrm{T} \times \mathrm{M} \times \mathrm{e} /\left(\begin{array}{lll}
1 & 000 & 000
\end{array}\right)
$$

Denklemde $\mathrm{T}$ yük ağırlığını, $\mathrm{M}$ taşıma mesafesini, e ise ton-km başı gram cinsinden $\mathrm{CO}_{2}$ emisyon miktarını göstermektedir.

\section{Bulgular ve Tartışma}

Çalışmada yapılan Hatay-Van arası vaka analizi için geliştirilen rotalar ve çok türlü taşımacılık rotalarındaki ulaşım türü değişim noktaları Tablo1'de gösterilmektedir. Bir adet tek türlü karayolu taşımacılık rotası ve üç adet çok türlü taşımacılık rotası geliştirilmektedir. Tabloda da görüldügü gibi çok türlü rotalar karayolu, demiryolu ve feribot taşımacılığından oluşmaktadır. Ulaşım coğrafyasından kaynaklı olarak denizyolu taşımacıllığı yapılamamaktadır. Feribot taşımacılığı ise TCDD’nın desteği ile yapilmaktadır.

Tablo1. Hatay-Van arasında geliştirilen tek türlü ve çok türlü taşımacılık rotaları ve tür değişim

\begin{tabular}{|c|c|c|c|c|c|}
\hline Ulaşım Rotası & $\begin{array}{l}\text { Başlangıç } \\
\text { Noktası }\end{array}$ & $\begin{array}{l}\text { 1. Ulaşım } \\
\text { Modu }\end{array}$ & $\begin{array}{l}\text { 1. Mod } \\
\text { Değişim } \\
\text { Noktası }\end{array}$ & $\begin{array}{l}\text { 2. Ulaşım } \\
\text { Modu }\end{array}$ & $\begin{array}{l}\text { Varış } \\
\text { Noktası }\end{array}$ \\
\hline Tek türlü Karayolu & \multirow{4}{*}{ Hatay } & Karayolu & - & - & \multirow{4}{*}{ Van } \\
\hline Çok türlü 1 & & Demiryolu & Siirt & Karayolu & \\
\hline Çok türlü 2 & & Demiryolu & Bitlis & Karayolu & \\
\hline Çok türlü 3 & & Demiryolu & Bitlis & Feribot & \\
\hline
\end{tabular}
noktalar1

Ulaşım rotalarında kullanılan ulaşım türlerine göre mesafe dağılımları Tablo 2'de verilmektedir. Tablodaki mesafe dağılımları incelendiğinde, çok türlü taşımacılık rotalarının demiryolu taşımacılığı odaklı olduğu göze çarpmaktadır. 
Tablo 2. Hatay-Van arasında geliştirilen tek türlü ve çok türlü taşımacılık rotalarındaki türlere göre mesafe dağılımları

\begin{tabular}{lrr}
\hline Ulaşım Rotası & & Mesafe \\
\hline & Karayolu(km) & Demiryolu (km) \\
\cline { 2 - 3 } Tek türlü Karayolu & 879 & - \\
Çok türlü 1 & 264 & 783 \\
Çok türlü 2 & 152 & 834 \\
Çok türlü 3 & 15,70 & 834 \\
\hline
\end{tabular}

\subsection{Yakıt tüketimi hesabı}

Karayolu taşımacılığında yakıt tüketimini yükün ağırlığı etkilediği için hesaplar üç farklı yük tonajı için yapılmaktadır. Hatay-Van arası taşımacılık rotaları için yakıt tüketimi Denklem 1 ve 2'ye göre hesaplanmakta ve Tablo 3 'teki sonuçlar elde edilmektedir.

Tablo 3. Hatay-Van arasında geliştirilen tek türlü ve çok türlü taşımacılık rotalarında hesaplanan yakıt tüketim miktarları

\begin{tabular}{llcl}
\hline Ulaşım Rotası & \multicolumn{3}{c}{ Yakıt Tüketim Miktarı (It) } \\
\cline { 2 - 4 } & $\mathbf{5}$ ton & $\mathbf{1 0}$ ton & $\mathbf{1 4}$ ton \\
Tek Türlü Karayolu & 544,30 & 561,21 & 574,73 \\
Çok Türlü 1 & 173,26 & 178,34 & 182,40 \\
Çok Türlü 2 & 104,55 & 107,47 & 109,81 \\
Çok Türlü 3 & 20,15 & 20,45 & 20,69 \\
\hline
\end{tabular}

Hatay ve Van arasında yapılan taşımacılık türlerine göre yakıt tüketim grafiği Şekil 1'de verilmektedir. Grafikte karayolu taşımacılığı ile diğer ulaşım türlerine kıyasla açık ara fazla yakıt tüketildiği görülmektedir. Yük tonajının artışı ulaşım türleri içerisinde yakıt tüketiminde çok fark yaratmamaktadır. En az yakıt tüketimi, demiryolu ve feribot taşımacılığının birleşiminden oluşan çok türlü 3 rotasında görülmektedir. Bu da çok türlü taşımacılığı, tek türlü taşımacılığa kıyasla yakıt tüketimi açısından oldukça avantajlı duruma getirmektedir.

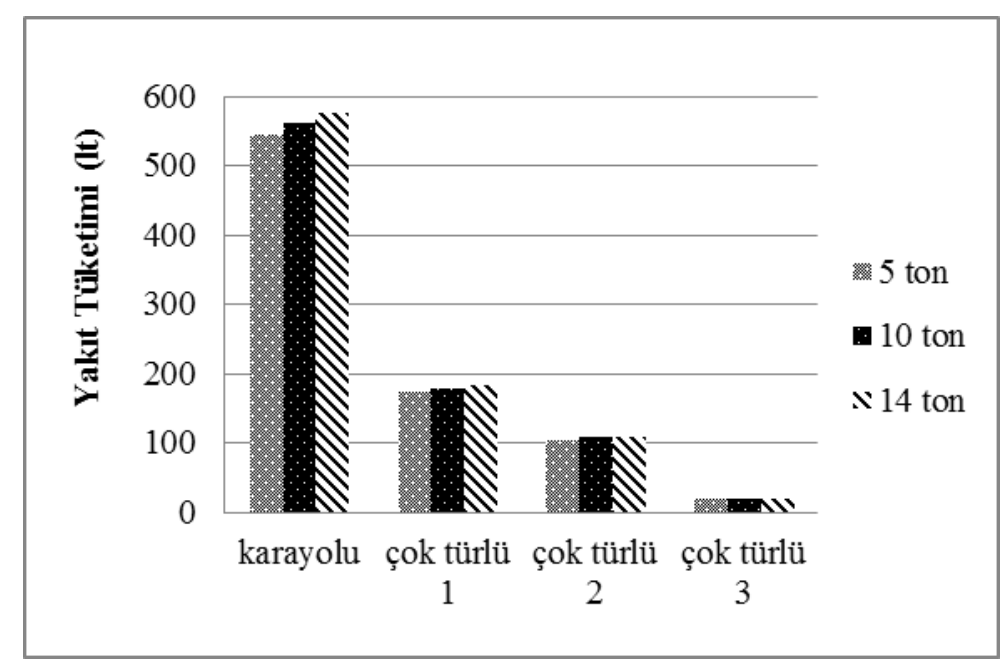

Şekil 1. Hatay-Van arası ulaşım türlerine göre yakıt tüketim miktarları

\subsection{Maliyet hesabı}

Hatay'dan Van'a yapılacak olan konteyner yük taşımacılığı rotaları için maliyet hesapları Denklem 2 ve 3'e göre hesaplanmaktadır. Hatay'dan Van'a demiryolu ağında Bitlis'ten sonra yük treni feribotla Van'a taşınmaktadır. TCDD’nin İstasyonlar Arası Mesafe ve Taşıma Ücreti Raporundan alınan ton başı birim fiyat tarifesine göre Hatay ve Bitlis arası maliyet 72,91 TL/ton ve Bitlis'ten feribot ile taşımacılık 
31,50 TL/ton olarak alınmaktadır. Konteynerin vagona yükleme ücreti $80 \mathrm{TL} /$ konteyner alınmaktadır [33]. Maliyet hesap sonuçları Tablo 4'te verilmektedir.

Tablo 4. Hatay-Van arasında geliştirilen tek türlü ve çok türlü taşımacılık rotalarında hesaplanan konteyner başı maliyet

\begin{tabular}{llll}
\hline Ulaşım Rotası & \multicolumn{3}{c}{ Maliyet (TL/t) } \\
\cline { 2 - 4 } & $\mathbf{5}$ ton & $\mathbf{1 0}$ ton & $\mathbf{1 4}$ ton \\
Tek Türlü Karayolu & 560 & 291 & 214 \\
Çok Türlü 1 & 270 & 188 & 166 \\
Çok Türlü 2 & 203 & 155 & 143 \\
Çok Türlü 3 & 148 & 142 & 110 \\
\hline
\end{tabular}

Karayolu taşımacılığında, yük tonajının artmasına bağlı olarak birim maliyetlerde azalma meydana gelmektedir. Güzergâhlar incelendiğinde minimum birim maliyet her üç yük birimi içinde çok türlü 3 güzergâhında gözlenmektedir. En yüksek birim maliyet Türkiye'de yaygın olarak yapılan tek türlü karayolu rotasında hesaplanmaktadır. Karayolu ve çok türlü 3 rotalarının birim maliyetleri karşılaştırıldığında taşımacılığın karayolu yerine çok türlü taşımacılıkla yapılması ile \%74'e varan tasarruf sağlanmaktadır.

Şekil 2'de ulaşım modlarına ve yük tonajına göre maliyet analizi verileri görülmektedir. Grafik incelendiğinde çok türlü 3 ulaşım türünün diğer türlere göre en ucuz taşımacılık olduğu açıça görülmektedir. En maliyetli taşımacılık ise üç yük birimi içinde karayolu taşımacılığıdır. Güzergâh kombinasyonları içerisinde bulunan demiryolu taşımacılığı oranına göre maliyetlerdeki artışın açık bir şekilde etkilendiği görülmektedir.

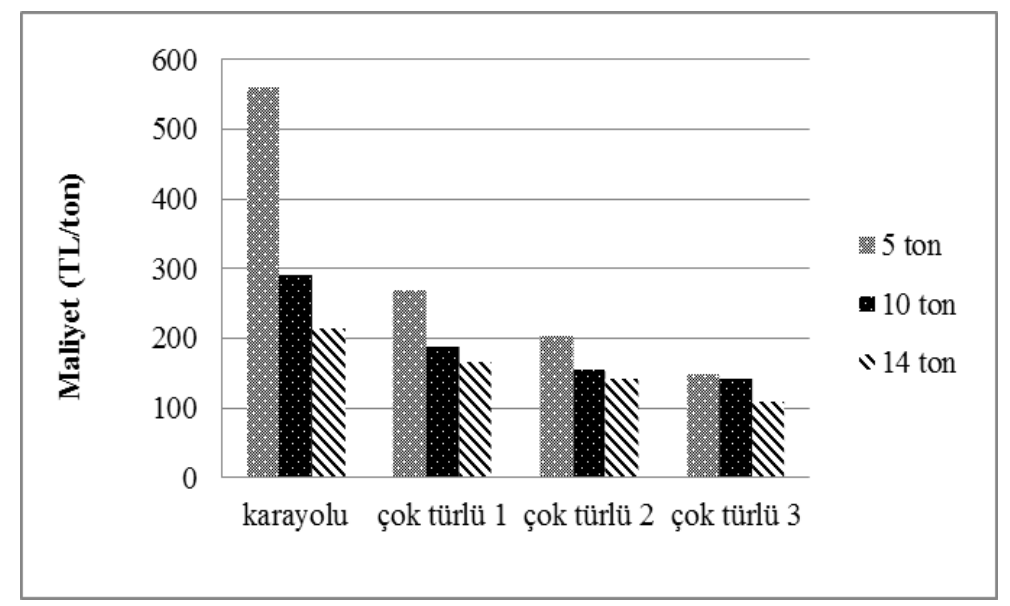

Şekil 2. Hatay-Van arası ulaşım modlarına göre ton başı maliyet değerleri

\subsection{Taşımacılık süresi hesabı}

Her güzergâh için materyal metot bölümünde verilen Denklem 5 ve 6 dikkate alınarak taşımacılık süresi hesapları yapılmakta ve hesap sonuçları Tablo 5 'te sunulmaktadır.

Tablo 5. Hatay-Van arasında geliştirilen tek türlü ve çok türlü taşımacılık rotalarında hesaplanan taşımacılık süresi

\begin{tabular}{ll}
\hline Ulaşım Rotası & Taşımacılık Süresi (sa) \\
\hline Tek Türlü Karayolu & 26,4875 \\
Çok Türlü 1 & 16,2357 \\
Çok Türlü 2 & 15,5642 \\
Çok Türlü 3 & 13,8605 \\
\hline
\end{tabular}

Hatay-Van arasında tasarlanan güzergâh senaryolarının taşımacılık süreleri değerleri Şekil 3'te karşılaştırılmaktadır. En hızlı taşımacılık güzergâhı 13,86 saat ile çok türlü 3’tür. Karayolu 
taşımacılığına bakıldığında çok türlü 3 rotasına göre \%50 daha yavaştır. Doğu Anadolu Bölgesinde gerekli demiryolu altyapı yatırımlarının yapılması ile demiryolu taşımacılığı daha çok geliştirilmelidir. Böylelikle Doğu Anadolu Bölgesinin taşımacılık sektörü bakımından kalkınması sağlanacaktır.

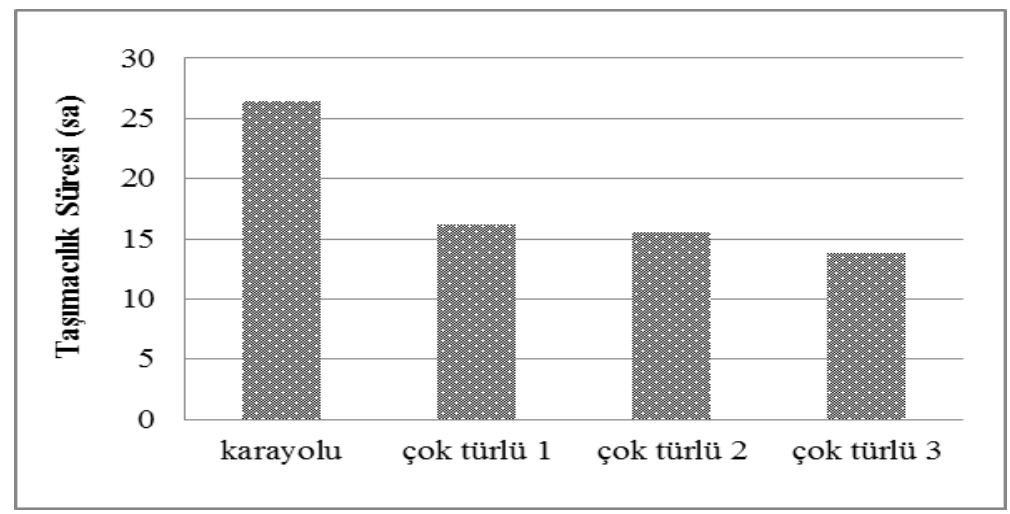

Şekil 3. Hatay-Van arası ulaşım modlarına göre taşımacılık süresi dağılımları

\subsection{Emisyon hesabı}

Hatay ve Van arasında gerçekleştirilen güzergahların emisyon hesapları Denklem 7 ve 8'e göre hesaplanmaktadır. Emisyon hesap sonuçları Tablo 6'da verilmektedir.

Tablo 6. Hatay-Van arasında geliştirilen tek türlü ve çok türlü taşımacılık rotalarında hesaplanan emisyon miktarlar1

\begin{tabular}{llcl}
\hline Ulaşım Rotası & \multicolumn{3}{c}{ Emisyon Miktarı (gr) } \\
\cline { 2 - 4 } & $\mathbf{5}$ ton & $\mathbf{1 0}$ ton & $\mathbf{1 4}$ ton \\
Tek Türlü Karayolu & 2918,651 & 11674,606 & 16930,728 \\
Çok Türlü 1 & 590,6919 & 2362,7675 & 4114,1201 \\
Çok Türlü 2 & 464,28 & 1857,1129 & 3473,299 \\
Çok Türlü 3 & 383,0827 & 1532,3309 & 3002,2941 \\
\hline
\end{tabular}

Şekil 4'te ulaşım modları ve taşınan yükün ağırlığına bağlı olarak hesaplanan emisyon miktarları verilmektedir. Grafik incelendiğinde minimum emisyon miktarı çok türlü 3 güzergahında görülmektedir. En fazla $\mathrm{CO}_{2}$ salınımı ise 16933,06 gr ile 14 ton yükün karayolu ile taşınmasında gerçekleşmektedir. Ülkemizde yurtiçi yük taşımacılığında ağırlıklı karayolunun tercih edilmesinden dolayı, taşımacılıktan kaynaklanan emisyon değerleri oldukça yüksek çıkmaktadır. Taşımacılığın demiryoluna kaydırılması $\mathrm{CO}_{2}$ salınımının indirgenmesinde oldukça etkili olacağı açık bir şekilde görülmektedir.

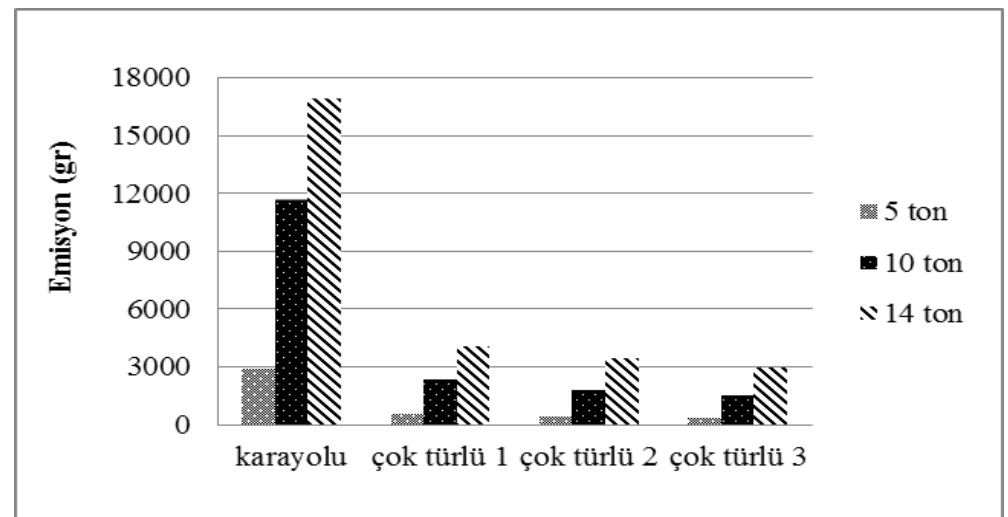

Şekil 4. Hatay-Van arası ulaşım modlarına göre emisyon miktarları

Hatay ve Van arasında geliştirilen güzergâh senaryolarının performans indeksi değerleri Şekil 5 'deki grafikte görülmektedir. Grafiğe göre performansı en yüksek güzergâh 5, 10, 14 ton için sırasıyla 
\%97,88, \%96,48 ve \%96,02 performans ile çok türlü taşımacılık güzergâhı en verimli çıkmaktadır. En verimsiz güzergâh ise grafikte görüldüğü gibi tüm yük birimleri içinde karayolu taşımacılık güzergâhıdır.

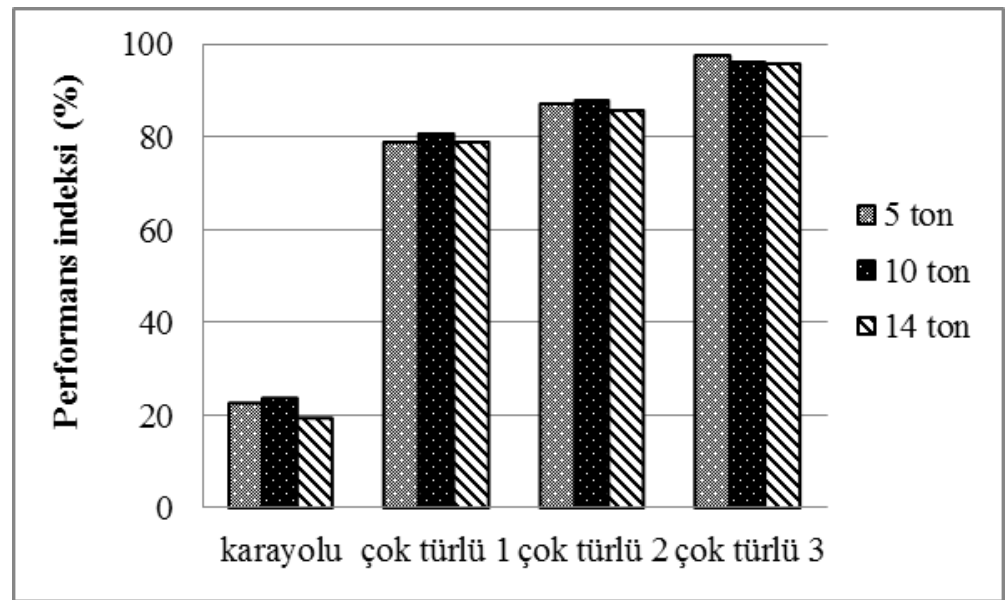

Şekil 5. Hatay-Van arası güzergâhların performans indeksleri

\section{Sonuç}

Yük taşımacılı̆̆ında rotaların önceden belirlenerek lojistiğin planlı olarak yapılması maliyetlerin, taşıma süresinin, yakıt tüketiminin ve emisyon değerlerinin düşmesinde etkili olmaktadır. Bunlara ek olarak planlı bir şekilde çok türlü taşımacılığın kullanılması bahsedilen karar değişkenlerindeki miktarların optimum seviyelere çekilmesinde büyük rol oynamaktadır. Hatay-Van arasında yaptığımız bu vaka analizi ile bunlar hesaplarımızda net bir şekilde görülmektedir.

Yakıt tüketimi ele alındığında, rotalar arası karşıllaştırmada minimum yakıt tüketimi 20,15-20,69 litre ile çok türlü 3 güzergâhında görülmektedir. En fazla yakıt tüketimi ise 544,30-574,73 litre ile tek türlü karayolu taşımacılığında görülmektedir. Taşımacılığın tek türlü karayolundan çok türlü taşımacılığa kaydırılması ile yakıt tüketiminde ciddi oranlarda tasarruf sağlanabilmektedir.

Rotalardaki ulaşım türlerine göre hesaplanan birim maliyet değerleri incelendiğinde, en ucuz taşımacılık $148 \mathrm{TL} / \mathrm{t}-110 \mathrm{TL} / \mathrm{t}$ aralı̆̆ ile çok türlü 3 rotasında yapılabilmektedir. Karayolu taşımacılığında bu durum $560 \mathrm{TL} / \mathrm{t}-214 \mathrm{TL} / \mathrm{t}$ aralığında seyretmektedir. Çok türlü 3 rotası ile Türkiye'de yaygın olarak yapılan karayolu taşımacılığına göre oldukça fazla ekonomik bir yük taşımacıllı̆ı yapılabilmektedir.

Taşımacılık sürelerine göre rotalar incelendiğinde en hızlı taşımacılık 13,86 saat ile çok türlü 3 rotası ile yapılmaktadır. Geleneksel taşımacılık türü olan karayolu ile taşımacılık süresi 26,49 saate ç1kmaktadır.

Güzergâhlar karbondioksit salınım miktarlarına göre ele alındığında, en çevreci rota çok türlü 3 rotasıdır. Çevreye en çok karbondioksit salınımının yapıldığı rota ise tek türlü karayolu taşımacılık rotasidir.

Dört güzergâh karar değişkenine göre rotaları eş zamanlı olarak değerlendirmek amacıyla performans indeksi değerlerine baktığımızda, \%97,88-\%96,02 performans aralığ 1 ile en efektif rota çok türlü 3'tür. Performans1 en zayıf rota ise \%22,54-\%19,21 performans aralığı ile tek türlü karayoludur.

Çalışma sonucunda görüldüğü gibi ulaşım coğrafyasından kaynaklı olarak bazı tek türlü taşımacılıkların yapılamadığı lokasyonlarda, çok türlü taşımacılığın yapılması ile yük taşımacıllı̆ında avantaj sağlayan demiryolu ve denizyolu ulaşım türlerinin katkısı arttırılabilmektedir. Yük taşımacılığında önemli yere sahip demiryolu ve denizyolu taşımacılık modlarının altyapı eksikliklerinin giderilmesi, yük taşımacılığının gelişmesine önemli ölçüde katkı sağlayacaktır.

\section{Kaynaklar}

[1] Demirlioğlu H. 2008. Türkiye'nin Denizyolu Konteyner Taşımacılığının, Kombine Taşımacılık ile Geliştirilmesi. Yüksek Lisans Tezi, İstanbul Teknik Üniversitesi Fen Bilimleri Enstitüsü, 106s, 
İstanbul.

[2] Ateş A., Karadeniz Ş., Esmer S. 2010. Dünya Konteyner Taşımacılığı Pazarında Türkiye'nin Yeri. Dokuz Eylül Üniversitesi Denizcilik Fakültesi Dergisi, 2 ( 2): 83-98.

[3] Ateş A., Esmer S., Çakır E., Balcı K. 2013. Karadeniz Konteyner Terminallerinin Göreceli Etkinlik Analizi. Dokuz Eylül Üniversitesi Denizcilik Fakültesi Dergisi, 5 (1): 1-22.

[4] Tanır, B. 2009. Marmara Bölgesindeki Karayolu Yük Taşımacılığına Alternatif Kombine Taşımacılık Sistemlerinin Araştırılması. Yüksek Lisans Tezi, Gazi Üniversitesi Fen Bilimleri Enstitüsü, 135s, Ankara.

[5] Göde M.G. 2011. Yük ve Yolcu Taşımacılığında Göller Bölgesi İçin Kombine Taşımacılık Sistemlerinin Araştırılması. Yüksek Lisans Tezi, Süleyman Demirel Üniversitesi, Fen Bilimleri Enstitüsü, 148s, Isparta.

[6] Sahin B., Yilmaz H., Ust Y., Guneri A.F., Gulsun B., Turan E. 2014. An Approach for Economic Analysis of Intermodal Transport. The Scientific World Journal, 2014: 1-11.

[7] Cansız O.F., Arslan T., Çubuk M.K., Çalışıcı M. 2008a. Türkiye Demiryollarında Enerji Tüketim Analizi. 2. International Railway Symposium \& Trade Exhibition, pp: 287-306, 15-17 Ekim, İstanbul.

[8] Cansız O.F., Arslan T., Çubuk M.K., Çalışıcı M. 2008b. Yük Taşımacılığında Demiryollarından Uzaklaşan Türkiye'nin Enerji Kaybının İncelenmesi. 2. International Railway Symposium \& Trade Exhibition, pp: 241-254, 15-17 Ekim, İstanbul.

[9] Çubuk K., Cansız O.F. 2005a. Türkiye'de Ulaşım Sistemleri Arasındaki Enerji Durumu. 24. Enerji Verimliliği Haftası Etkinlikleri, 17-18, Ankara.

[10] Çubuk K., Cansız O.F. 2005b. Energy Status Between Transportation System in Turkey. 24. Enerji Verimliliği Haftası Etkinlikleri, 47-49, Ankara.

[11] Cansız O.F. 2007. Enerji Politikalarının Ulaştırma Sistemlerinin Optimizasyonu ile Geliştirilmesi ve Uygulamadan Elde Edilen Getirilerin Ortaya Konması. Doktora Tezi, Gazi Üniversitesi, Fen Bilimleri Enstitüsü, 352s, Ankara.

[12] Cansız O.F., Çubuk M.K., Çalışıcı M. 2009. An Energy Analysis of Road Transportation in Turkey, Proceedings of the 3rd International Conference on Energy and Development Environment - Biomedicine, pp: 91-95, 29-31 December 2009, Athens.

[13] Vitoşoğlu Y., Evren G. 2008. Türkiye'de Demiryolu Ağırlıklı Kombine Yük Taşımacılığı Olanaklarının Araştırılması. İtü Dergisi/d mühendislik, 7 (1): 77-88.

[14] Atar F. 2013. Kısa Mesafe Deniz Taşımacılığının Avantajları ve Kombine Taşımacılıktaki Önemi. Yüksek Lisans Tezi, İstanbul Teknik Üniversitesi Fen Bilimleri Enstitüsü, 89s, İstanbul.

[15] Balık İ., Aksay K., Şenbursa N. 2015. Marine Transportation in Turkey ans Future Perspective. Turkish Journal of Maritime and Marine Sciences, 1 (1): 48-60.

[16] Saatçioğlu C., Saygılı M.S. 2013. İntermodal Taşımacılıkta Denizyolu- Demiryolu Entegrasyonunun Ekonomik ve Çevresel Açıdan Değerlendirilmesi. Journal of ETA Maritime Science, 1 (2): 19-26.

[17] Sahin B., Yilmaz H., Ust Y., Guneri A.F., Gulsun, B. 2009. An approach for analysing transportation costs and a case study. European Journal of Operational Research, 193 (1): 1-11.

[18] Ozbay K., Bartin B., Yanmaz-Tuzel O., Berechman J. 2007. Alternative methods for estimating full marginal costs of highway transportation. Transportation Research Part A: Policy and Practice,41 (8): 768-786.

[19] Janic M. 2007. Modelling the full costs of an intermodal and road freight transport network. Transportation Research Part D: Transport and Environment, 12 (1): 33-44.

[20] Chang T.S. 2008. Best routes selection in international intermodal networks. Computers \& operations research, 35 (9): 2877-2891.

[21] TÜİK. 2005. Sektörlere ve Kullanım Alanlarına Göre Nihai Enerji Tüketimi.

[22] Demiryolu ve Karayolu Kaşımacılığında http://www.ustaokan.com/?Syf=26\&Syz=530815 (Erişim tarihi: 22.05 .2018 )

[23] Cansız O.F., Ünsalan K. 2018. Cost analysis of çok türlü freight transportation: a case of Iskenderun, International Journal of Advanced Engineering Research and Science, 5 (5): 315 319.

[24] https://portal1.tcddtasimacilik.gov.tr/tcdd(bD10ciZjPTIwMCZkPW1pbg==)/zy02/yuktasimafiy atlari, (Erişim tarihi: 10.02.2018). 
[25] Araç Kullanma ve Dinlenme Sürelerine Uyma Mecburiyeti ve Denetleme Esaslar1. https://www.tugem.com.tr/mevzuat?mlid=2528 (Erişim tarihi: 12.03.2018)

[26] Şehirlerarası Çift Yönlü Karayollarında Hız Sınırı. www.kgm.gov.tr (Erişim tarihi: 05.05.2018)

[27] Demiryolunda Rekabetçi Çözümler - $\quad$ Hizlı Trenler. https://railturkeyakademi.wordpress.com/2015/04/08/demiryolunda-rekabetci-cozumler-hizlitrenler/\#more-399 (Erișim tarihi: 29.04.2018).

[28] Yang H., Chen W. 2017. Retailer-driven Carbon Emission Abatement with Consumer Environmental Awareness and Carbon Tax: Revenue-sharing Versus. Omega, 78: 179-191.

[29] Zhang S.J., Niu T.L., Wu Y., Zhang K.M., Wallington T.J., Xie Q.Y., Wu X.M., Xu H.L. 2018. Fine-Grained Vehicle Emission Management Using İntelligent Transportation System Data. Environmental Pollution, 241: 1027-1037.

[30] Kishimoto P.N., Karplus V.J., Zhong M., Saikawa E., Zhang X., Zhang X. 2017. The Impact of Coordinated Policies on Air Pollution Emissions from Road Transportation in China. Transportation Research Part D: Transport and Environment, 54: 30-49.

[31] Bayrak M.R. 2012. Sürdürülebilir Kalkınma İçin Türkiye'de Düşük Karbon Ekonomisi ve Kyoto Protokolü'nün Finansman Kaynakları/Low Carbon Economy and Financial Sources of The Kyoto Protocol for Sustainable Development in Turkey. Journal of History Culture and Art Research, 1 (4): 266-279.

[32] Guidelines for Measuring and Managing $\mathrm{CO}_{2}$ Emission from Freight Transport Operationshttp://www.cefic.org (Erişim tarihi: 02.03.2018)

[33] Kaya O. 2018. Öztrans Lojistik-Lojistik Operasyon Müdürü Telefonla Kişisel Görüşme. 